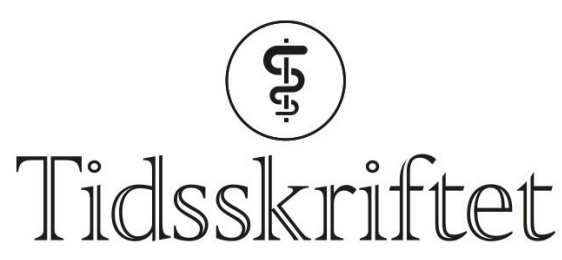

DEN NORSKE LEGEFORENING

\title{
Få år mellom kohortene
}

KOMMENTAR

\section{NIKLAS STARCK WESTERBERG}

E-post: niklas.starck.westerberg@ahus.no

Niklas Starck Westerberg er LIS1.

Forfatteren har ikke oppgitt noen interessekonflikter.

I Tidsskriftets utgave 10/2019 ble det publisert en artikkel om jobb-hjem-balanse i to kohorter av norske leger (1). Hva tenker forfatterne om at det kun er 6 år mellom de to kohortene? Er det vesentlig forskjell i arbeidssituasjonen mellom kohortene? Dette representerer jo kun at den ene gruppen ble ferdige på legestudiet samtidig som den andre begynte. Er det virkelig grunn til å tro på en endring på så kort tid eller er det mer sannsynlig at dette representerer statistisk støy?

\section{LITTERATUR:}

1. Hertzberg TK, Tyssen R, Skirbekk H et al. Jobb-hjem-balanse i to kohorter av norske leger. Tidsskr Nor Legeforen 2019; 139. doi: 10.4045/tidsskr.18.0339. [PubMed][CrossRef]

Publisert: 9. september 2019. Tidsskr Nor Legeforen. DOI: 10.4045/tidsskr.19.0523

(C) Tidsskrift for Den norske legeforening 2020. Lastet ned fra tidsskriftet.no 